\section{Diurnal Effects on Mentha canadensis Oil Concentration and Composition at Two Different Harvests}

\author{
Santosh Shiwakoti, Henry Y. Sintim, and Shital Poudyal \\ University of Wyoming, Department of Plant Sciences and Sheridan \\ Research and Extension Center, 3401 Coffeen Avenue, Sheridan, WY 82801

\section{Jennifer Bufalo} \\ U.S. Department of Agriculture, Agricultural Research Service, Natural Products \\ Utilization Research Unit, Thad Cochran Center, University, MS 38677; and the \\ Department of Botany, Institute of Biosciences (IB), UNESP-Univ. Estadual \\ Paulista, P.O. Box 510, 18618-970, Botucatu, Sao Paulo, Brazil
}

\section{Charles L. Cantrell}

U.S. Department of Agriculture, Agricultural Research Service, Natural Products Utilization Research Unit, Thad Cochran Center, University, MS 38677

\section{Tess Astatkie}

Dalhousie University, Faculty of Agriculture, 50 Pictou Road, P.O. Box 550, Truro, NS B2N 5E3, Canada

\section{Ekaterina Jeliazkova and Lyn Ciampa}

University of Wyoming, Department of Plant Sciences and Sheridan Research and Extension Center, 3401 Coffeen Avenue, Sheridan, WY 82801

Valtcho D. Zheljazkov ${ }^{1}$

University of Wyoming, Department of Plant Sciences and Sheridan Research and Extension Center, 3401 Coffeen Avenue, Sheridan, WY 82801; and Oregon State University, Columbia Basin Agricultural Research Center, 48037 Tubbs Ranch Road, P.O. Box 370, Pendleton, OR 97801

Additional index words. Mentha arvensis, essential oil concentration, essential oil composition, menthol, menthone

Abstract. Japanese cornmint, also known as menthol mint (Mentha canadensis L. syn M. arvensis $\mathbf{L}$.), is an essential oil crop cultivated in several countries in Asia and South America. The plant is currently the only commercially viable source for natural menthol as a result of the high concentration of menthol in the oil compared with other crops. The hypothesis of this study was that harvesting at regular intervals within a 24-hour period would have an effect on essential oil concentration and composition of Japanese cornmint grown at high altitude in northern Wyoming. Flowering plants were harvested every 2 hours on 7 to 8 Aug. and on 14 to 15 Aug. and the essential oil was extracted by steam distillation and analyzed by gas chromatography-mass spectroscopy (GC-MS). The effects of harvest date (Harvest 1 and Harvest 2) and harvest time (12 times within a 24-hour period) were significant on oil concentration and yield of menthol, but only harvest date was significant on the concentration of menthol in the oil. The interaction effect of harvest date and harvest time was significant on water content and on the concentrations of menthol and menthofuran in the oil and on the yield of limonene, menthol, and menthofuran. Overall, the oil concentration in grams per $100 \mathrm{~g}$ dried material for the two harvests $(1.26$ and 1.45 , respectively), the concentration of menthol in the oil $(67.2 \%$ and $72.9 \%$, respectively), and menthol yield (1066 to $849 \mathrm{mg} / 100 \mathrm{~g}$ dried biomass) were higher in plants at Harvest 2 as compared with plants at Harvest 1 . The oil concentration was higher in plants harvested at $1100 \mathrm{HR}$ or at $1300 \mathrm{HR}$ and lowest in the plants harvested at $1500 \mathrm{HR}$. Menthol yield was the highest in plants harvested at $1300 \mathrm{HR}$ and lowest in the plants harvested at $0700 \mathrm{HR}, 1900 \mathrm{HR}$, or at $0300 \mathrm{HR}$. This study demonstrated that harvesting time within a 24 -hour period and harvest date (maturity of the crop) may affect essential oil concentration and composition of Japanese cornmint grown at high altitude in northern Wyoming.

Japanese cornmint (Mentha canadensis L. syn $M$. arvensis L.) is an industrial crop cultivated for its essential oil, which has wide personal uses and industrial applications.
2002; Lawrence, 2007; Zheljazkov et al., 2010a). Japanese cornmint is grown in India, China, Japan, Paraguay, and Brazil (Lawrence, 2007; Singh and Saini, 2008), and to a limited extent in eastern Europe (Topalov and Zheljazkov, 1991; Zheljazkov et al., 1996).

Menthol is an important monoterpene used in the pharmaceutical, therapeutic, food, and cosmetic industries (Lawrence, 2007). Menthol and the dementholized oil have a stable market (Lawrence, 2007). Menthol and Japanese cornmint essential oil has been used for treatment of insomnia, nasal congestion, inflammation, irritable bowel syndrome, bad breath, headache, and other infections (Farco and Grundmann, 2013; Patel et al., 2007). Besides its medical uses, menthol is used widely in personal care products such as moisturizers, lip balms, chewing gums, and bathing products (Lawrence, 2007; Ram et al., 2006).

The United States is a major importer and user of menthol and dementholized oil; however, there is no production of natural menthol in this country. Introducing Japanese cornmint to the United States will provide a new high-value crop for American growers and domestic production of natural menthol. Previous studies indicated feasibility of growing Japanese cornmint in Mississippi (Zheljazkov et al., 2010a, 2010b) and in Wyoming (Zheljazkov et al., 2013). Although there has been research on the timing of harvest representing the stage of development of the crop on Japanese cornmint in the south of the United States (Zheljazkov et al., $2010 \mathrm{~b}$ ), there is no information on how harvest time within a $24-\mathrm{h}$ period would affect oil concentration and composition of Japanese cornmint grown in a more northern climate.

Diurnal variations in essential oil content and composition of aromatic plants from the same family have been reported previously for clary sage (Salvia sclarea L.) (Shevchenko, 1973; Tsvetkov and Balinova-Tsvetkova, 1976), for lavender (Lavandula angustifolia Mill.) (Hassiotis et al., 2010), and for basil (Ocimum gratissimum L.) (De Vasconcelos Silva et al., 1999). Additionally, a recent study on 'Native' spearmint in northern Wyoming reported a significant effect of diurnal changes on spearmint essential oil content and composition (Bufalo et al., 2015). The effect of diurnal changes on Japanese cornmint in North America has not been investigated. Such information would be important for domestic producers of Japanese cornmint Therefore, the objective of this study was to evaluate the effect of harvest time within a 24-h period $(0700 \mathrm{HR}, 0900 \mathrm{HR}, 1100 \mathrm{HR}$, $1300 \mathrm{HR}, 1500 \mathrm{HR}, 1700 \mathrm{HR}, 1900 \mathrm{HR}, 2100 \mathrm{HR}$, $2300 \mathrm{HR}, 0100 \mathrm{HR}, 0300 \mathrm{HR}$, and $0500 \mathrm{HR}$ ) and harvest date (Harvest 1 and Harvest 2) on essential oil concentration and composition of Japanese cornmint.

\section{Materials and Methods}

Field and laboratory experiments. The Japanese cornmint is the only commercially viable source for production of natural menthol because its essential oil contains high concentrations of menthol (Galeotti et al., study was conducted in 2013 at the Sheridan Research and Extension Center Experimental Fields (long. $44^{\circ} 45.686^{\prime} \mathrm{N}$, long. $-106^{\circ} 55.479^{\prime}$ 
$\mathrm{W}$, elevation $1170 \mathrm{~m}$ above sea level). In this study, we used Japanese cornmint cultivar Arvensis 3 of Mentha canadensis L. (synonym M. arvensis L.). The Japanese cornmint plantation was established in 2011 with land preparation, weed control, fertilization, and irrigation as described previously (Zheljazkov et al., 2013).

Harvesting and drying. Japanese cornmint was harvested twice with a 2-week period between two harvests in Aug. 2013. Plants were harvested at $\approx 10$ to $12 \mathrm{~cm}$ above the soil surface; samples included all parts (stems, leaves, and inflorescences). The samples were obtained at each harvest time within the 24-h period on 7 Aug. and 8 Aug. for the first harvest date and on 14 Aug. and 15 Aug. for the second harvest date. The Japanese cornmint was flowering at the time of both harvests. During the first harvest, the mints had $\approx 25 \%$ of open flowers on the inflorescence of the main stem, whereas during the second harvest, the mint plants had almost $100 \%$ open flowers on the main stem. Japanese cornmint usually is harvested at full flowering to ensure the highest essential oil concentration and the highest concentration of menthol in the oil (Topalov, 1989). Harvests within the 24-h period were conducted every $2 \mathrm{~h}$ from $0700 \mathrm{HR}$ to $0500 \mathrm{HR}$ on the next day. Each harvest was replicated three times; hence, the total number of biomass samples, $500 \mathrm{~g}$ fresh weight each, was 72. The 72 samples for essential oil extraction were dried at a shady place in a well-ventilated barn $\left(20\right.$ to $\left.25{ }^{\circ} \mathrm{C}\right)$ for 4 weeks before the oil extraction. To determine the water content of each sample at harvest, a second set of fresh samples, $1 \mathrm{~kg}$ each, was generated from each plot and dried in a dryer at $65^{\circ} \mathrm{C}$ until constant weight was achieved.

Distillation. The 72 dried Japanese cornmint biomass samples were steam-distilled for $60 \mathrm{~min}$ in 2-L steam distillation units to extract the essential oil as described previously (Gawde et al., 2009; Zheljazkov et al., 2010a, 2010b).

The beginning of each distillation was measured when the first drop of essential oil was deposited from the condenser and into the separator. At the end of the $60 \mathrm{~min}$, the power was turned off, and the oil and the water were decanted from the separator into glass vials. The oil was separated from the

Received for publication 1 Oct. 2014. Accepted for publication 19 Nov. 2014.

This research was funded in part by the 2011 Sun Grant Initiative Program project and by the Department of Plant Sciences funds awarded to Dr. Valtcho Jeliazkov (Zheljazkov)

We thank the people who helped us in harvesting, namely Andrew Burkhardt, Rebecca Moreland, and Jermiah Vardiman. We also thank Solomon Green III and Amber Reichley for helping with the analyses. We acknowledge the critical review of the manuscript and the suggestions by Mr. Osama Saleh of University of Wyoming and Dr. Alex Martynenko of Dalhousie University.

${ }^{1}$ To whom reprint requests should be addressed; e-mail valtcho.jeliazkov@oregonstate.edu or valtcho. pubs@gmail.com. water; oil weight was measured on an analytical scale, and the oil was stored in a freezer at $-14{ }^{\circ} \mathrm{C}$ until all samples were extracted and could be analyzed. The essential oil concentration (yield) was calculated as grams of oil per $100 \mathrm{~g}$ of dry herbage.

Gas chromatography-flame ionization detection quantification of essential oil components. Japanese cornmint oil samples from all treatments and replications were analyzed by $\mathrm{GC}$-flame ionization detection (FID) on an Agilent 7890 A GC System (Agilent Technologies, Santa Clara, CA) using GC equipped with a DB-5 column (30 $\mathrm{m} \times 0.25-\mathrm{mm}$ fused silica cap. column, film thickness of $0.25 \mu \mathrm{m}$ ) operated using the following conditions: injector temperature, $240{ }^{\circ} \mathrm{C}$; column temperature, 60 to $240{ }^{\circ} \mathrm{C}$ at 3 ${ }^{\circ} \mathrm{C} / \mathrm{min}$, held at $240{ }^{\circ} \mathrm{C}$ for $5 \mathrm{~min}$; carrier gas, helium; injection volume, $5 \mu \mathrm{L}$ (split on FID, split ratio 25:1); detector temperature for FID was $300{ }^{\circ} \mathrm{C}$. Commercial standards (R)-(+)-limonene, (-)-menthol, $(+)$-menthofuran, (-)-menthone were obtained from Fluka, Analytical (Sigma-Aldrich, St. Louis, MO). Linearity was imposed by using response factors (RF) and regression coefficients independently. Response factors were calculated using the equation $\mathrm{RF}=\mathrm{DR} / \mathrm{C}$, where DR was the detector response in peak area (PA) and $\mathrm{C}$ is the concentration of the analyzed substance. The chromatograms of each of the essential oil samples from all harvests and replicates were compared with the chromatograms from standards. Target peaks were confirmed by retention time. Confirmed integrated peaks were used to determine the percentage of each chemical constituent in the essential oil. The RF of the target chemical constituent was used to determine the percentage of that constituent in each essential oil sample using the equation $(\mathrm{PA} / \mathrm{RF} / \mathrm{C}) \times 100=\%$ (peak area/response factor/concentration).

Statistical analysis. The effect of harvest date and harvest time (12 levels: $0700 \mathrm{HR}, 0900$ $\mathrm{HR}, 1100 \mathrm{HR}, 1300 \mathrm{HR}, 1500 \mathrm{HR}, 1700 \mathrm{HR}, 1900 \mathrm{HR}$, $2100 \mathrm{HR}, 2300 \mathrm{HR}, 0100 \mathrm{HR}, 0300 \mathrm{HR}$, and $0500 \mathrm{HR}$ ) on water (\%), oil concentration (oil content $\mathrm{g} / 100 \mathrm{~g}$ dry weight), the concentration (\%), and yield (mg/100 g dried material) of limonene, menthol, menthone, and menthofuran was determined using analysis of variance of a $2 \times 12$ factorial design. The analysis was completed using the Mixed Procedure of SAS (SAS Institute Inc., 2010), and the validity of model assumptions (normal distribution and constant variance of the error terms assumptions; randomization of the run orders ensured the independence of the error terms assumption) was verified by examining the residuals as described in Montgomery (2013). The normality assumption was violated for limonene yield; however, it was valid after applying a square root transformation. Although the letter groupings are generated using the transformed values, the presented means are back-transformed to the original scale. For the responses with significant $(P<0.05)$ and marginally significant ( $P$ value between 0.05 and 0.1 ) in- teraction effect, the significance of the main effect(s) was ignored and multiple means comparison was completed by comparing the least squares means of the 24 combinations of harvest and time using the lsmeans statement of the Mixed Procedure of SAS (SAS Institute Inc., 2010). However, for the responses with a non-significant interaction effect, but significant main effect(s), least squares means of the corresponding two harvest dates and/or 12 harvest times were compared (SAS Institute Inc., 2010). In both significant main effect and interaction effect cases, because a large number of means is being compared, letter grouping was done at the $1 \%$ level of significance to reduce the overinflation of Type I experimentwise error rate.

\section{Results and Discussion}

The main effects of harvest date and harvest time were significant on oil concentration (content) and the yield of menthol, whereas only the main effect of harvest date was significant on the concentration of menthol in the oil (Table 1). The interaction effect of harvest date and harvest time (time of the day) was significant on water content, on the concentrations of menthone and menthofuran in the oil, and on the yield of limonene, menthone, and menthofuran (Table 1).

The concentration of menthone $(6.8 \%$ to $15.4 \%$ of the total oil) was the highest in the oil of the plants harvested at 1300 HR during Harvest 1 and was the lowest in the oil of the plants harvested at $0700 \mathrm{HR}$ during Harvest 2 (Fig. 1). The concentration of menthofuran (1.1\% to $1.76 \%$ of the total oil) was the highest in plants harvested at $0100 \mathrm{HR}$ during Harvest 2 and the lowest in the plants harvested at $0700 \mathrm{HR}$ or $1700 \mathrm{HR}$ to $2100 \mathrm{HR}$ during Harvest 2. The concentration of menthofuran in plants during Harvest 1 was unaffected by the time of harvest.

Limonene yield (a function of oil concentration and the concentration of limonene in the oil) was higher in plants during Harvest 2 at $1300 \mathrm{HR}$ and $0100 \mathrm{HR}$ and lower in Harvest 1 plants harvested at the harvest times other than $1100 \mathrm{HR}$ and $1300 \mathrm{HR}$ (Fig. 2). On the other hand, menthone yield was the highest in Harvest 1 plants harvested at $1100 \mathrm{HR}$ and $1300 \mathrm{HR}$ and the lowest in plants at $0300 \mathrm{HR}$ during Harvest 1 or at $0700 \mathrm{HR}$ during Harvest 2 (Fig. 2). Menthofuran yield was the highest in plants at $0100 \mathrm{HR}$ during Harvest 2 and the lowest in plants at $0700 \mathrm{HR}$ during Harvest 2 (Fig. 2). There was no significant difference in menthofuran yield in plants harvested during Harvest 1 (Fig. 2).

Overall, the oil concentration (content) in dry tissue was the highest in plants harvested at $0100 \mathrm{HR}$, but it was not significantly higher than that harvested at $0900 \mathrm{HR}$ to $1700 \mathrm{HR}$, $2100 \mathrm{HR}$ to $2300 \mathrm{HR}$, and at $0500 \mathrm{HR}$ (Table 2). Also, generally, menthol yield was the highest in plants harvested at $1300 \mathrm{HR}$ and lower in the plants harvested at $0700 \mathrm{HR}, 1900 \mathrm{HR}$, and 0300 HR (Table 2).

The oil concentration and the concentration and yield of menthol in the oil were 
Table 1. Analysis of variance $P$ values for the main and interaction effects of harvest date $(\mathrm{H})$ and harvest time (T) on water content, oil concentration, the concentration, and yield (yld) of limonene, menthol, menthone, and menthofuran.

\begin{tabular}{|c|c|c|c|c|c|c|c|c|c|c|}
\hline $\begin{array}{l}\text { Source of } \\
\text { variation }\end{array}$ & Water & $\begin{array}{c}\text { Oil } \\
\text { concn }\end{array}$ & Limonene & Menthol & Menthone & Menthofuran & $\begin{array}{c}\text { Limonene } \\
\text { yld }\end{array}$ & $\begin{array}{c}\text { Menthol } \\
\text { yld }\end{array}$ & $\begin{array}{c}\text { Menthone } \\
\text { yld }\end{array}$ & $\begin{array}{c}\text { Menthofuran } \\
\text { yld }\end{array}$ \\
\hline$\overline{\mathrm{H}}$ & 0.001 & $0.001^{z}$ & 0.304 & 0.009 & 0.001 & 0.767 & 0.003 & 0.001 & 0.001 & 0.003 \\
\hline $\mathrm{T}$ & 0.109 & 0.005 & 0.471 & 0.214 & 0.284 & 0.001 & 0.040 & 0.004 & 0.049 & 0.001 \\
\hline $\mathrm{H}^{*} \mathrm{~T}$ & 0.014 & 0.174 & 0.159 & 0.635 & 0.001 & 0.004 & 0.063 & 0.105 & 0.001 & 0.005 \\
\hline
\end{tabular}

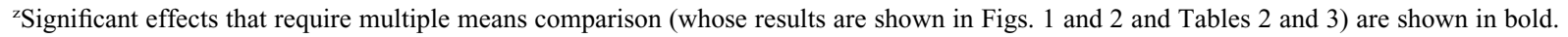
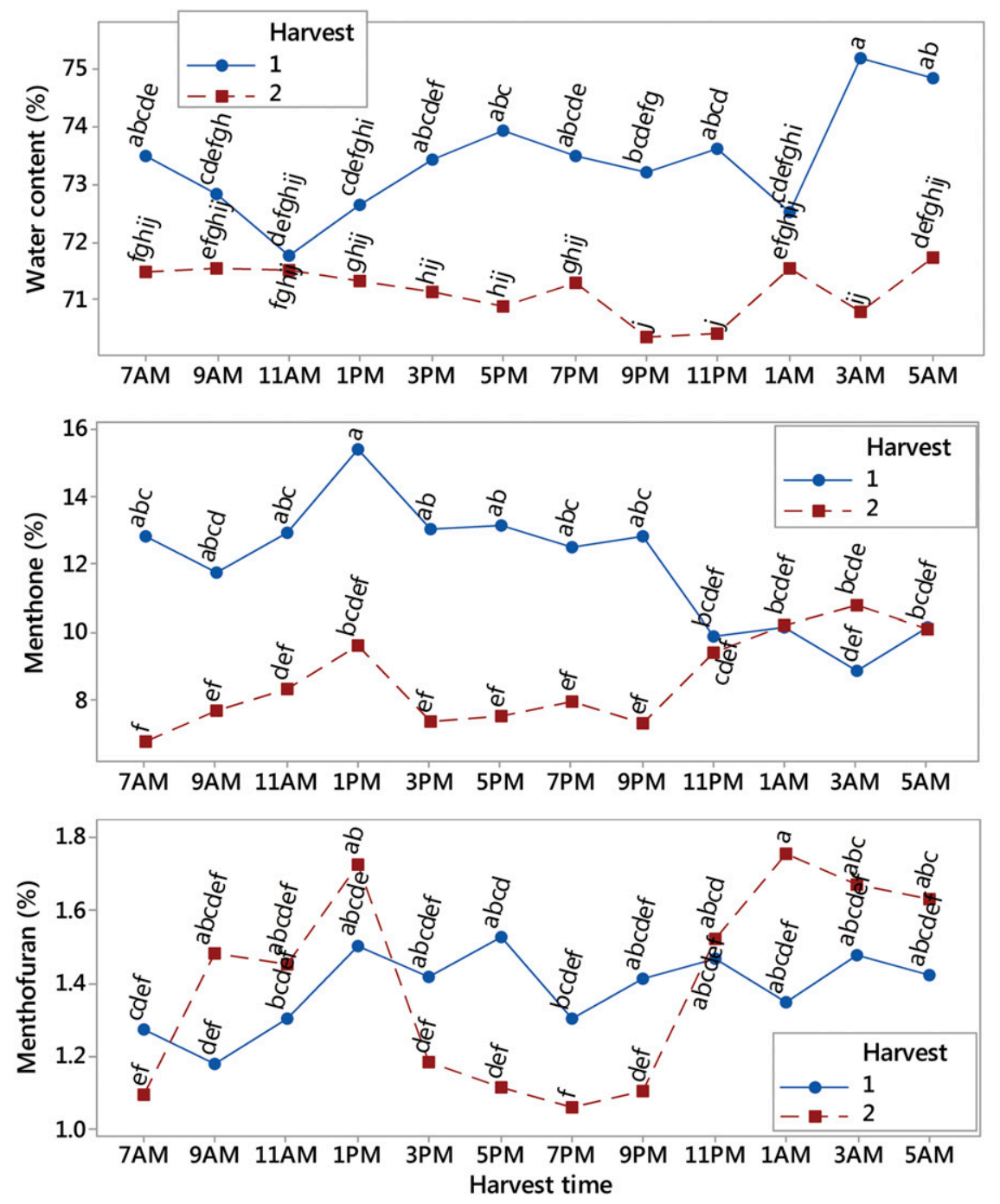

Fig. 1. Interaction plot of water content (\%), and the concentrations (\%) of menthone and menthofuran obtained from the two harvests and the 12 harvest times. Within each plot, means sharing the same letter are not significantly different.

higher during Harvest 2 than during Harvest 1 regardless of harvest time (Table 3 ). The averages at Harvest 1 and Harvest 2 were $1.26 \%$ and $1.45 \%, 67.2 \%$ and $72.9 \%$, and 849 and $1066 \mathrm{mg} / 100 \mathrm{~g}$ dried herbage, respectively.

Time of the day is one of the main factors to be accounted for when harvesting aromatic plants for good quality and quantity of the essential oil (Filho et al., 2006; Zheljazkov et al., 2010b, 2013). The effects of harvest date and time of the day had a significant effect on the concentration of essential oil, limonene, menthol, menthone, and menthofuran and hence confirms the hypothesis of the study that harvesting at regular intervals within a $24-\mathrm{h}$ period would have an effect works on Japanese cornmint. Rajeswara Rao et al. (2000), Singh et al. (2002), and Topalov and Zheljazkov (1991) reported 13.9\%, 11.7\%, and $12.8 \%$, respectively, on their studies.
Menthone concentrations were higher in oil obtained during Harvest 1 (25\% flowering) than in oil obtained during Harvest 2 (100\% flowering), which is supported by the Topalov and Zheljazkov (1991) study. The latter authors reported higher menthone concentration in oil obtained from plants harvested at $50 \%$ flowering than in oil obtained from plants harvested at $100 \%$ flowering. Similarly, Peiris et al. (1982) also reported a falling of menthone concentration as plant development progresses toward flowering. According to Peiris et al. (1982), there is a dramatic change in menthone concentration in oil obtained from plants harvested at the vegetative stage $(81.4 \%)$ or at the full bloom stage $(4.8 \%)$. Menthofuran is considered a toxic chemical, which is in very low concentration in plants. The highest concentration of menthofuran in our study was $1.53 \%$, which is lower than that reported in the study by Topalov and Zheljazkov (1991) and higher than that in the studies by Lawrence (1983) and Voronina et al. (1990).

As expected, menthol was the major constituent of the Japanese cornmint oil in our study. Although menthol yield is affected significantly by timing of harvest, no distinct pattern was observed. Menthol was highest when the plants were harvested at the fullbloom stage; however, Topalov and Zheljazkov (1991) reported no difference or marginal difference between the compositions in oil obtained from $50 \%$ flowering plants and full-bloomed plants. In contrast, Peiris et al. (1982) mentioned that the concentration of menthol in the oil increases dramatically when the plants reach the full-bloom stage. The average menthol concentration in the oil of our study was $70.02 \%$ and is in agreement with other research findings on Japanese cornmint (Gasic et al., 1992; Lawrence, 1983; Peiris et al., 1982; Rajeswara Rao et al., 2000; Singh et al., 2002; Zheljazkov et al., 2013). In a study with two cultivars of Japanese cornmint in the same region as this study, menthol concentration in the oil varied from $67 \%$ to $85 \%$ depending on harvest date (Zheljazkov et al., 2013). In a study with the same cultivar of Japanese cornmint grown in Mississippi in 2008, menthol concentration of the oil varied from $78 \%$ during the first cut to $73 \%$ in the second cut (Zheljazkov et al., 2010a). Harvesting date also modified the concentration of menthol in Japanese cornmint cv. Arvensis 3 grown in Mississippi (Zheljazkov et al., 2010b).

\section{Conclusion}



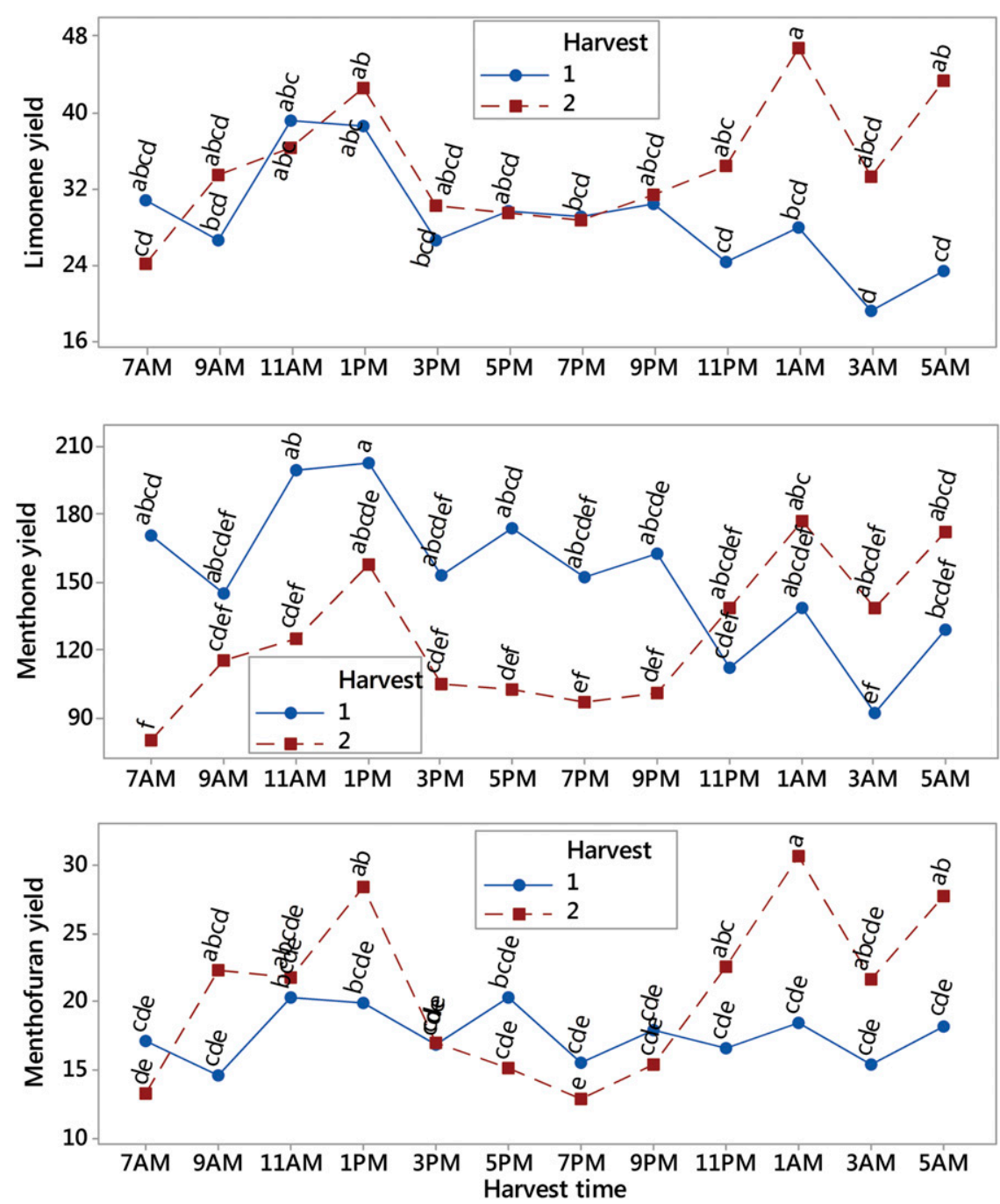

Fig. 2. Interaction plot of yields ( $\mathrm{mg} / 100 \mathrm{~g}$ dried herbage) of limonene, menthone, and menthofuran obtained from the two harvests and the 12 harvest times. Within each plot, means sharing the same letter are not significantly different.

Table 2. Mean oil concentration and menthol yield obtained from the 12 harvest times.

\begin{tabular}{lcc}
\hline Time & $\begin{array}{c}\text { Oil concn } \\
(\mathrm{g} / 100 \mathrm{~g} \mathrm{dry} \mathrm{wt})\end{array}$ & $\begin{array}{c}\text { Menthol yield } \\
(\mathrm{mg} / 100 \mathrm{~g} \text { dried material) }\end{array}$ \\
\hline $0700 \mathrm{HR}$ & $1.26 \mathrm{bc}^{\mathrm{z}}$ & $805 \mathrm{c}$ \\
$0900 \mathrm{HR}$ & $1.37 \mathrm{abc}$ & $925 \mathrm{abc}$ \\
$1100 \mathrm{HR}$ & $1.52 \mathrm{ab}$ & $1,075 \mathrm{abc}$ \\
$1300 \mathrm{HR}$ & $1.48 \mathrm{ab}$ & $1,206 \mathrm{a}$ \\
$1500 \mathrm{HR}$ & $1.31 \mathrm{abc}$ & $939 \mathrm{abc}$ \\
$1700 \mathrm{HR}$ & $1.33 \mathrm{abc}$ & $948 \mathrm{abc}$ \\
$1900 \mathrm{HR}$ & $1.20 \mathrm{c}$ & $798 \mathrm{c}$ \\
$2100 \mathrm{HR}$ & $1.31 \mathrm{abc}$ & $878 \mathrm{bc}$ \\
$2300 \mathrm{HR}$ & $1.30 \mathrm{abc}$ & $948 \mathrm{abc}$ \\
$0100 \mathrm{HR}$ & $1.54 \mathrm{a}$ & $1,124 \mathrm{ab}$ \\
$0300 \mathrm{HR}$ & $1.17 \mathrm{c}$ & $815 \mathrm{c}$ \\
$0500 \mathrm{HR}$ & $1.48 \mathrm{ab}$ & $1,030 \mathrm{abc}$ \\
\hline
\end{tabular}

${ }^{\mathrm{z}}$ Within each response variable, means followed by the same letter are not significantly different.

Table 3. Mean oil concentration, and the concentration and yield of menthol obtained from the two harvests.

\begin{tabular}{lccc}
\hline & Oil concn & Menthol & Menthol yield \\
Harvest & $(\mathrm{g} / 100 \mathrm{~g}$ dry material $)$ & $(\%)$ & $67.2 \mathrm{~b}$ \\
\hline 1 & $1.26 \mathrm{~b}^{\mathrm{z}}$ & $72.9 \mathrm{a}$ & $849 \mathrm{~b}$ \\
2 & $1.45 \mathrm{a}$ & $\mathrm{mg} / 100 \mathrm{~g}$ dried material $)$ \\
\hline
\end{tabular}

${ }^{\mathrm{z}}$ Within each response variable, means followed by different letters are significantly different.

grown in a northern climate. Harvest date also significantly affected oil concentration (content) and composition. However, the observed changes, although significant, were not dramatic. Therefore, from practical perspectives, Japanese cornmint grown in north- ern Wyoming can be harvested any time during a 24-h period. For best oil concentration and high menthol concentration in the oil, Japanese cornmint 'Arvensis 3' should be harvested during full flowering. Japanese cornmint grown under the northern Wyoming climate accumulated a significant amount of menthol.

\section{Literature Cited}

Bufalo, J., V.D. Zheljazkov, C.L. Cantrell, T. Astatkie, L. Ciampa, and E. Jeliazkova. 2015. Diurnal effects on spearmint oil yields and composition. Sci. Hort. 182:73-76.

De Vasconcelos Silva, M.G., A.A. Craveiro, F.J. Abreu Matos, M.I.L. Machado, and J.W. Alencar. 1999. Chemical variation during daytime of constituents of the essential oil of Ocimum gratissimum leaves. Fitoterapia 70:32-34.

Farco, J.A. and O. Grundmann. 2013. MentholPharmacology of an important naturally medicinal 'cool.' Mini Rev. Med. Chem. 13:124131.

Filho, J.L.S.C., A.F. Blank, P.B. Alves, P.A.D. Ehlert, A.S. Melo, S.C.H. Cavalcanti, M. de F. Arrigoni-Blank, and R. Silva-Mann. 2006. Influence of the harvesting time, temperature and drying period on basil (Ocimum basilicum L.) essential oil. Braz. J. Pharm. 16:24-30.

Galeotti, N., L. Di Cesare Mannelli, G. Mazzanti, A. Bartolini, and C. Ghelardini. 2002. Menthol: A natural analgesic compound. Neurosci. Lett. 322:145-148

Gasic, O., N. Mimica-Dukic, and D. Adamovic. 1992. Variability of content and composition of essential oils of different Mentha arvensis L. var. piperascens cultivars. J. Essent. Oil Res. 4:49-56.

Gawde, A.J., C.L. Cantrell, and V.D. Zheljazkov. 2009. Dual extraction of essential oil and podophyllotoxin from Juniperus virginiana. Ind. Crops Prod. 30:276-280.

Hassiotis, C.N., D.M. Lazari, and K.E. Vlachonasios. 2010. The effects of habitat type and diurnal harvest on essential oil yield and composition of Lavandula angustifolia Mill. Fresenius Environ. Bul. 19:1491-1498.

Lawrence, B.M. 1983. Progress in essential oils (cornmint oil). Flavour Fragrance J. 8:61-66.

Lawrence, B.M. 2007. Mint: The genus Mentha. CRC Press, Boca Raton, FL.

Montgomery, D.C. 2013. Design and analysis of experiments. 8th Ed. Wiley, New York, NY.

Patel, T., Y. Ishiuji, and G. Yosipovitch. 2007. Menthol: A refreshing look at this ancient compound. J. Amer. Acad. Dermatol. 57:873-878.

Peiris, B.D., S. Balasubramaniam, A.L. Jayawardene, and H.M.W. Herath. 1982. Effect of plant maturity on oil composition of two mint varieties recently introduced to Sri Lanka. J. Natl. Sci. Council of Sri Lanka. 10:143-147.

Rajeswara Rao, B.R., P.N. Kaul, G.R. Mallavarapu, and S. Ramesh. 2000. Comparative composition of whole herb, flowers, leaves and stem oils of cornmint (Mentha arvensis L.f. piperascens Malinv. ex. Holmes). J. Essent. Oil Res. 12: 357-359.

Ram, D., M. Ram, and R. Singh. 2006. Optimization of water and nitrogen application to menthol mint (Mentha arvensis L.) through sugarcane trash mulch in a sandy loam soil of semi-arid subtropical climate. Bioresour. Technol. 97:886-893.

SAS Institute Inc. 2010. SAS/STAT® 9.3 user's guide. SAS Institute Inc., Cary, NC.

Shevchenko, S.V. 1973. Seasonal and diurnal changes in Salvia sclarea essential oil content. Rastitel'nye Resursy. 9:566-570. 
Singh, M. and S. Saini. 2008. Planting date, mulch, and herbicide rate effects on the growth, yield, and physicochemical properties of menthol mint (Mentha arvensis). Weed Technol. 22:691-698.

Singh, K., B.R. Rajeswara Rao, P.N. Kaul, G.R. Mallavarapu, and S. Ramesh. 2002. Comparative performance of menthol mint (Mentha arvensis L.f. piperascens Malinv. ex. Holmes) cultivars in semi-arid tropical climate. J. Spices and Aromatic Crops. 11:67-69.

Topalov, V. and V. Zheljazkov. 1991. Effect of harvesting stages on the yield of fresh material, essential oil and planting material from Mentha piperata Huds. and Mentha arvensis L. Herba Hungarica. 30:60-67.
Topalov, V.D. 1989. Mentha, p. 372-381. In: Topalov, V.D., I.I. Dechev, and M.S. Pehlivanov (eds.). Plant production. Zemizdat Press, Sofia, Bulgaria.

Tsvetkov, R. and A. Balinova-Tsvetkova. 1976 Studies on the extraction of essential oil from Salvia sclarea in Bulgaria. Rasteniev"dni Nauki 13:26-37.

Voronina, E.P., L.B. Dimitriev, and I.I. Greenberg. 1990. Composition of the essential oil of certain mint species and varieties introduced in Central Botanic Garden. Izvestiya Timiryazevskoi Sel'skokhozyaistvennoi Akademii. 4:166170.

Zheljazkov, V., B. Yankov, and V. Topalov. 1996. Effect of mechanical and chemical weed control on the growth, development, and produc- tivity of Mentha piperita and Mentha arvensis var. piperascens grown for planting material. J. Essent. Oil Res. 8:171-176.

Zheljazkov, V.D., C.L. Cantrell, and T. Astatkie. 2010a. Study on Japanese cornmint in Mississippi. Agron. J. 102:696-702.

Zheljazkov, V.D., C.L. Cantrell, and T. Astatkie. 2010b. Yield and composition of Japanese cornmint fresh and dry material harvested successively. Agron. J. 102:1652-1656.

Zheljazkov, V.D., C.L. Cantrell, T. Astatkie, and E. Jeliazkova. 2013. Mentha canadensis L., a subtropical plant, can withstand first few fall frosts when grown in northern climate. Ind Crops Prod. 49:521-525. 